Research Article

\title{
New record of blue striped snapper, lutjanus notatus (cuvier, 1828) (family: lutjanidae), from indian waters
}

\begin{abstract}
Single species of the blue striped snapper, Lutjanus notatus belonging to the family Lutjanidae, was first time collected from the Visakhapatnam, India. The specimen (156 $\mathrm{mm}$ Standard length) was caught by deep sea trawl net. The present study deals with detail description of the species given here with illustration. In addition, pre dorsal scales origin at first dorsal spine and those are extend from first dorsal spine to inter orbital region and pre dorsal scales rows were 12 . Transverse check scales were 10 ; there is no gap between temporal scale bands of each side, Inter orbital with scaly sheath. The present study confirms the presence of Lutjanus notatus in Indian coast.
\end{abstract}

Keywords: Ichthyology, Rare species, L. notatus, Andhra Pradesh, India
Volume 5 Issue 2 - 2017

\author{
Govinda Rao Velamala, Krishna Naranji M, \\ Ramesh Babu K \\ Department of Marine Living Resources, Andhra University, \\ India
}

Correspondence: Govinda Rao Velamala, Department of Marine Living Resources, Andhra University, India, Tel 09440395067,Email govnidarao.mlru.com

Received: January 10, 2017| Published: February 02, 2017

\section{Introduction}

The rare blue striped snapper Lutjanus notatus (Cuvier, 1828) (Lutjanidae) is a reef fish found relatively large distribution around the western Indian Ocean. It is harvested as a food source, but is not a commercial species. ${ }^{1}$ Rare blue striped snapper belongs to the fishes of the family Lutjanidae. This is one of the largest families in the order perciformes and comprises 4 subfamilies, 17 genera and 110 species, mainly found on coral reefs in tropical and subtropical regions of the Atlantic and Indo-Pacific. ${ }^{2,3}$ The largest subfamily is Lutjaninae with six genera Hoplopagrus, Lutjanus, Macolor, Ocyurus, Pinjalo and Rhomboplites with about 72 species. The genus Lutjanus has about 64 species. ${ }^{4,5}$ Here we described the morphological characteristics of Lutjanus notatus have added them to the Indian Ichthyofauna. Previously many reports were recorded from Mainland of India. New record of low fin scorpion fish Scorpaenodes parvipinnis from Indian waters. ${ }^{6}$ first time recorded of Rama Rao's scorpion fish, Scorpaenopsis ramaraoi from Andhra Pradesh Coast. ${ }^{7}$ First record of golden barred butterfly fish Roa Jayakari from Visakhapatnam coast. ${ }^{8}$ first record of spiny snout squirrel fish Middle East coast of India. ${ }^{9}$ rare sharp tail mola Masturus lanceolatus recorded from coastal waters of Visakhapatnam. ${ }^{10}$

\section{Materials and methods}

Single specimen of the Lutjanus notatus was collected from Visakhapatnam coastal waters, India $\left(17^{\circ} 44^{\prime} \mathrm{N}, 8^{\circ} 23^{\prime} \mathrm{E}\right)$ during the period 2013-2015. Specimen of L. notatus was examined and identified as Lutjanus notatus. The color of the specimen in the samples was noted in fresh condition. Morphometric and meristic data of the fresh specimen were taken. Measurements were made with calipers. Methodology followed by. ${ }^{5,11}$ The specimens were preserved in $5 \%$ formaldehyde for further analysis.

\section{Results}

Lutjanus notatus (Cuvier, 1828) (Figure 1) Diacope notatus Cuvier (in C. \& V.), 1828, Hist. Nat. Poiss, 2: 422 (Type Locality: Indian Ocean).

\section{Morphometric and meristic data given in Table I}

Body fusiform, slender to moderately deep; dorsal profile convex; dorsal profile of head gently sloped; snout profile slightly concave; mouth large; maxilla reaches vertical below the midpoint of the eye; eyes are large in size; preorbital bone is narrow than the eye diameter; inter orbital slightly convex; vomerine tooth present without a medial posterior extension; tongue smooth without teeth; palatines present; pre opercle slightly produced at angle on ventral and serrated; upper profile straight with serrations; preopercle notch and knob is well developed. Lower profile rounded with serrations; opercle flap pointed and extended up to the vertical line of origin of the dorsal fin. Head covered with ctenoid scales, originating from inter orbital region and extending up to the base of the first dorsal fin; transverse scales rows on cheek ten. Body covered with ctenoid scales.

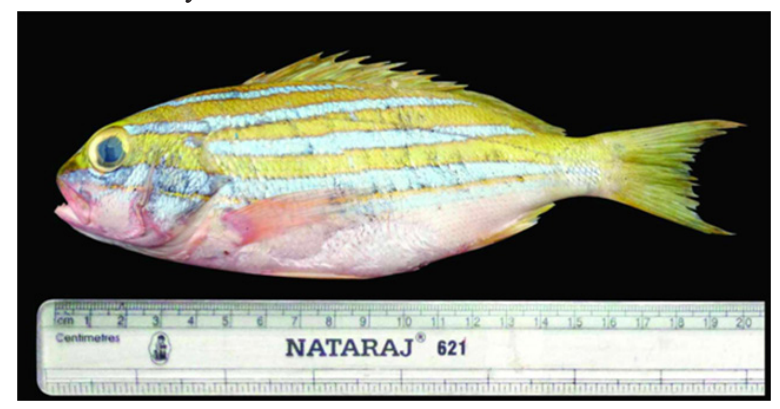

Figure I Lutjanus notatus. $201 \mathrm{~mm}$, TL.

Origin of dorsal and pelvic on same line and the origin of pectoral slightly anterior; fifth dorsal spine is longest and succeeding spines decrease in size; soft part of the dorsal fin slightly angular in shape; membrane between the spines is incised; first anal spine shorter than second and third; second anal spine longer and stouter than first and third spine; anal fin angular; pectoral fin pointed, extending up to posterior region of the anus; pelvic fin short; caudal fin emarginated; scales above the lateral line run appear as oblique rows and run straight and parallel below lateral line horizontal to it; below the lateral line, scales are parallel to the ventral side of the body; the scales on caudal peduncle run parallel to the lateral line. Soft parts of dorsal, anal and pectoral fins covered with scaly sheath; the lateral line is slightly arch shaped up to spinous dorsal end and runs down parallel to the dorsal profile.

\section{Colour}

Anterior part of back and upper part of head brownish; sides yellow, grading to pale yellowish-white ventrally; a series of four narrow blue 
stripes on sides, the upper most slanting posteriorly toward dorsal fin base; all fins mainly yellowish.

Table I Morphometric and meristic data of species L.notatus represented in the catches of Visakhapatnam, India.

\begin{tabular}{|c|c|}
\hline & Lutjanus notatus, $\mathrm{n}=\mathrm{I}$ \\
\hline Standard Length & $156 \mathrm{SL}$ \\
\hline Total Length & $|34.6|$ \\
\hline Body depth & 32.69 \\
\hline Head length & 37.17 \\
\hline Pre dorsal distance & 39.74 \\
\hline Pre pectoral distance & 37.17 \\
\hline Pre pelvic distance & 38.46 \\
\hline Pre anal distance & 66.02 \\
\hline Dorsal fin base & 53.84 \\
\hline Pectoral fin base & 14.74 \\
\hline Anal fin base & 5.76 \\
\hline Dorsal spine height & 14.74 \\
\hline Soft dorsal height & 9.61 \\
\hline Ist anal spine height & 24.35 \\
\hline 2nd anal spine height & 13.46 \\
\hline Soft anal height & 20.51 \\
\hline Pectoral length & 14.74 \\
\hline Pelvic spine length & 10.89 \\
\hline Soft pelvic length & 10.25 \\
\hline Head depth & 75.86 \\
\hline Head width & 53.44 \\
\hline Eye diameter & 25.86 \\
\hline Pre orbital distance & 25.86 \\
\hline Post orbital distance & 44.82 \\
\hline Inter orbital & 25.86 \\
\hline Upper jaw length & 36.20 \\
\hline Lower jaw length & 27.58 \\
\hline Maxillary width & 10.34 \\
\hline Snout length & 18.6 \\
\hline Dorsal & $X I I, 13$ \\
\hline Anal & $\mathrm{III}, 8$ \\
\hline Pectoral & 16 \\
\hline Ventral & I,5 \\
\hline Caudal & 16 \\
\hline Gill rakers & 20 \\
\hline Lateral line scales & 50 \\
\hline Pored scales & 45 \\
\hline Lateral transverse scales & $7+1+19$ \\
\hline
\end{tabular}

\section{Discussion}

Descriptions, meristic counts and morphometric data in the present study are in good agreement with that of. ${ }^{2,5,13}$ This species closely resembles Lutjanus bengalensis in body shape and coloration, but is separable from it in having gill rakers $26-28$ but in this species having 20 gill rakers. This is the new record from mainland of India. This is the rare species from Visakhapatnam coastal waters. This is the IUCN Red list of threatened species. ${ }^{1}$ Locally called as a "Aratikaya”.

\section{Distribution}

Western Indian Ocean: Mozambique, Natal in South Africa, Madagascar, Reunion and Mauritius.

\section{Habitat and Ecology}

The blue striped snapper inhabits coral reefs in tropical climates. It is found either individually or in groups of 5-10 individual species, at a depth range of $10-50 \mathrm{~m}$. This species feeds on small fishes and crustaceans.

\section{Acknowledgements}

The authors are thankful to Head, department of Marine Living Resources, Andhra University for providing facilities during the entire study period 2013-2016.

\section{Conflicts of interst}

None.

\section{References}

1. Collen B, Richman, N, Beresford, et al. Lutjanus notatus, The IUCN Red List of Threatened Species 2010: e. 2015

2. Allen GR FAO species catalogue Vol. 6 Snappers of the world: An annotated and illustrated catalogue of the lutjanid species known to date. FAO Fisheries Synopsis. 1985;125:1-208.

3. Eschmeyer WN Catalog of Fishes. Electronic version accessed. California Academy of Sciences, San Francisco. 2014

4. Froese R, Pauly D Fish Base. World Wide Web electronic publication. (April 2010 version). 2016

5. Nelson JS Fishes of the world. (4th edn), John Wiley \& Sons, USA, pp. 2006;345-347.

6. Muddula Krishna Naranji, Govinda Rao V. New record of low fin scorpion fish Scorpaenodes parvipinnisGarrett (1836) family Scorpaenidae from Indian waters. Adv Pha Toxicology. 2015;16 (3):69-74.

7. Muddula Krishna Naranji, Govinda Rao Velamala First record of Rama Rao's scorpionfish, Scorpaenopsisramaraoi Randall and Eschmeyer, 2001, Scorapenidae) from Visakhapatnam, Andhra Pradesh Coast, India FishTaxa. 2016;1(2):84-88.

8. Muddula Krishna N, Govinda Rao V, Venu D First record of golden barred butterfly fish, Roajayakari (Norman, 1939) (Pisces: Chaetodontidae) from Visakhapatnam coastal waters, eastcoast of India. J Ent Zool Studies. 2016;4(2):403-405.

9. Govinda Rao V, Muddula Krishna N, Venu D Ostichthys acanthorhinus(Randall, Shimizu \& Yamakawa, 1982). A first record of spiny snout squirrel fish (Beryciformes: Holocentridae) from Visakhapatnam, Middle East coast of India J Exp Zool India. 2016;19(2):667-669.

10. Muddula Krishna Naranji, Velamala Govinda Rao, Devara Venu. An occurrence of the rare sharp tail mola Masturus lanceolatus (Lienard, 1840) (Tetraodontiformes: Molidae) in the coastal waters of Visakhapatnam, India $\quad J$ Threatened Taxa. 2016;8(13):9592-9594.

11. Allen GR, White WT, Erdmann MV Two new species of snappers (Pisces: Lutjanidae:Lutjanus) from the Indo-West Pacific. $J$ Ocean Sci Foundation. 2013;6:35-51.

12. Hubbs CL, Lagler KF Fishes of the great Lake region. Cran brook Inst. Scientific Fish Bull. 1958;26:1-213.

13. Smith MM, Heemstra PC Smith's Sea Fishes. Springer-Verlag Publication, 1986;572-579. 